\title{
Zinc levels of serum and cervicovaginal secretion in recurrent vulvovaginal candidiasis
}

\author{
K Böhler, V Meisinger, H Klade, A Reinthaller
}

\begin{abstract}
Objective-To determine whether zinc deficiency in serum or vulvovaginal secretion is a risk factor for recurrent vulvovaginal candidiasis.

Design-Prospective and controlled study.
\end{abstract}

Setting-Department of Dermatology, University of Vienna.

Subjects-21 women who had experienced at least three documented episodes of acute vulvovaginal candidiasis within the previous 12 months. Fifteen women without anamnesis of vulvovaginal candidiasis as a control group.

Interventions-Blood samples were drawn for measurement of plasma zinc levels. Lavage of the vagina and ectocervix was performed with sterile saline solution for measurement of cervicovaginal zinc levels.

Main outcome measures-Zinc levels of serum and cervicovaginal secretions were determined by flame atomic absorption spectrophotometry.

Results-We found no significant difference in the mean zinc concentration of plasma and cervicovaginal secretions between the recurrent vulvovaginal candidiasis and the control group. ( $p$ value for serum $=0.71, p$ value for secretion $=0 \cdot 80)$. Zinc levels of plasma and cervicovaginal secretions showed no correlation (patient group: $r=-0.05$, control group: $\mathbf{r}=-0.07)$.

Conclusion-It is well known that zinc not only exerts a major impact on different immune functions, but also participates in growth and morphogenesis of Candida albicans. Our results could not confirm the previous hypothesis that zinc deficiency of serum is a risk factor in recurrent vulvovaginal candidiasis. It is possible that the local zinc level of cervicovaginal secretions essentially influences antifungal activity of third generation azole antimycotics.

(Genitourin Med 1994;70:308-310)

\section{Introduction}

There is still major controversy over the aetiology of recurrent vulvovaginal candidiasis (VVC). ${ }^{1}$ The majority of these patients lack well known predisposing factors, such as diabetes mellitus, oral contraceptives and antibiotic treatment. ${ }^{2}$ However, alterations in humoral as well as cell-mediated immunity have been ascertained in some patients suffering from recurrent VVC. ${ }^{3-5}$

Zinc, an essential trace element, has been shown to influence several cell-mediated immunologic mechanisms. ${ }^{6}$ Edman, et al. found significantly lower plasma zinc levels in women with recurrent VVC compared with the control group and concluded that mild zinc deficiency plays a role in the susceptibility of women to VVC. ${ }^{7}$ In addition several in vitro investigations have shown that zinc concentrations of culture media are directly related to growth and phenotypic conversion of the budding to the mycelial form of Candida albicans. ${ }^{8}$ These observations might imply notable effects on yeast adherence capacity and antifungal treatment results. This study was undertaken to measure zinc concentrations in plasma and vaginal secretion of women suffering from recurrent VVC as well as healthy controls in order to elucidate if local or systemic zinc deficiency is a risk factor for recurrent infection.

\section{Subjects and methods}

Thirty six non pregnant women aged between 20 and 49 years (mean 33.7) with regular menstrual cycles were included in the study after oral informed consent was obtained. Exclusion criteria were: symptomatic infection at the time of investigation, ingestion of zinc supplements within seven days and sexual intercourse within three days before investigation, because high zinc concentrations of seminal fluid would possibly falsify zinc levels of vaginal secretions. No attention was paid to the phase of the menstrual cycle. At the time of investigation all women selected for this study denied vulvovaginal complaints and were culture negative for Candida species. In addition bacterial vaginosis, Trichomonas vaginalis-, Neisseria gonorrhoeae-, Chlamydia trachomatis-, mycoplasma and ureaplasma infections were excluded by culture.

The patients were divided into two groups: the symptomatic group contained 21 women who had experienced at least three documented episodes of acute VVC within the previous 12 months. For detailed clinical data see table 1. Fifteen women served as a control group. None of the control subjects had ever suffered from vaginal candidiasis.

For zinc determinations $10 \mathrm{ml}$ of blood were drawn in the morning (8-10 am), after an overnight fast, by venipuncture using polyethylene syringes. Blood was centrifuged 
Table 1 Comparison of zinc levels in serum and cervicovaginal secretions in women with recurrent VVC and control subjects

\begin{tabular}{|c|c|c|c|c|c|}
\hline Graoup & No. & $\begin{array}{l}\text { Plasma zinc } \\
\mu g / d l \\
\text { mean, } S D\end{array}$ & No. & $\begin{array}{l}\text { Cervicovag.S. } \\
\mu g / d l \\
\text { mean, } S D\end{array}$ & $\begin{array}{l}\text { Spearman } \\
\text { correl. coeff. }\end{array}$ \\
\hline $\begin{array}{l}\text { Recurrent VVC } \\
\text { Control } \\
\text { Wilcoxon test result }\end{array}$ & $\begin{array}{l}21 \\
15\end{array}$ & $\begin{array}{l}109,17 \cdot 7 \\
107,12 \cdot 8 \\
p=0.71\end{array}$ & $\begin{array}{l}20 \\
15\end{array}$ & $\begin{array}{l}41,30 \cdot 2 \\
42,29.6 \\
p=0.80\end{array}$ & $\begin{array}{l}\mathbf{r}=-0.05 \\
\mathbf{r}=-0.07\end{array}$ \\
\hline
\end{tabular}

immediately at $900 \mathrm{~g}$ for 15 minutes and the plasma was stored at $-20^{\circ} \mathrm{C}$ until further analysis.

Cervicovaginal secretions were collected in 35 women (20 women of the symptomatic group, 15 women of the control group). Saline $(10 \mathrm{ml}$, sterile, $0.9 \%)$ was instilled into the cervical orae and $8 \mathrm{ml}$ of mucus and saline then aspirated from the vagina into a polyethylene syringe. Zinc concentrations were determined by flame atomic absorption spectrophotometry with a Perkin Elmer model 5100 (Überlingen, Germany). Plasma and cervicovaginal secretion samples were measured directly after a 1:5 dilution with distilled deionized water.

Wilcoxon 2-sample test (normal approximation) was used for analysis of significance. A value $<0.05$ was regarded as significant. For correlation analysis Spearman correlation coefficients were evaluated. A positive or negative correlation was assumed when $\mathrm{r}$ was $>0.7$.

\section{Results}

The results of zinc measurements in plasma and cervicovaginal secretions are demonstrated in table 1 . No significant difference could be found in the mean plasma zinc concentrations between the recurrent VVC and the control group $(109,17 \cdot 7 \mu \mathrm{g} / \mathrm{dl}$ and 107 , $12.8 \mu \mathrm{g} / \mathrm{dl}$ (mean, $\mathrm{SD}$ ) respectively; $\mathrm{p}=$ 0.71 ). Whereas plasma zinc values were exclusively within normal limits (68-136 $\mu \mathrm{g} / \mathrm{dl})$ in the control group, in the recurrent VVC group one patient revealed plasma zinc concentrations above $(143.4 \mu \mathrm{g} / \mathrm{dl})$ and one below $(65.3 \mu \mathrm{g} / \mathrm{dl})$ the normal limit.

No normal zinc values of cervicovaginal secretions have been established so far. Comparison of both groups revealed zinc concentrations of $41,30.2 \mu \mathrm{g} / \mathrm{dl}$ (mean, SD) in the recurrent VVC group and $42,29.6 \mu \mathrm{g} / \mathrm{dl}$ (mean, SD) in the control group. This difference was not significant $(p=0 \cdot 80)$. We could not find any positive correlation between the zinc concentrations in plasma and in cervicovaginal secretions in either group (recurrent VVC group: $r=-0.05$, control group: $r=-$ 0.07).

\section{Discussion}

Zinc has been known to be an essential nutritional element for more than 100 years. ${ }^{9}$ The amount of zinc available varies with alimentary supply, which varies with different diets, with the percentage absorbed by the digestive tract, and with the excretion rate. It has been suggested that zinc is absorbed primarily through the small intestine by active as well as passive transport mechanisms. Interactions between zinc and other metal cations and organic compounds encountered in the intestinal lumen dramatically affect absorption. ${ }^{6}$ In 1963 Prasad et al. were the first to report increased susceptibility to infection in association with primary zinc deficiency. ${ }^{10} \mathrm{~A}$ decade later Moynahan discovered that acrodermatitis enteropathica, an autosomally recessive disorder of zinc metabolism, is associated with an increased incidence of infections, primarily with candida. ${ }^{11}$ Accumulated data from human and animal studies suggest a major relationship between zinc deficiency and gross impairment of different immune functions. ${ }^{612}$ Edman et al. reported on the zinc status in women with recurrent VVC and suggested that mild zinc deficiency might play a role in the susceptibility to recurrent infection. ${ }^{7}$ They found significantly lower plasma zinc levels in women with recurrent VVC than in control subjects. However, no difference was noted in the erythrocyte zinc concentration between the two groups. Zinc levels of cervicovaginal secretions had not been assessed. In our study we were not able to confirm these results, as patients and control group exhibited comparable plasma zinc levels. Accordingly we cannot support Edman's conclusion that increased susceptibility to VVC is caused by plasma zinc deficiency. ${ }^{\text {? }}$

Non eradication of $C$. albicans is one of the most discussed causes of recurrent VVC. ${ }^{13}$ After therapy negative vaginal cultures turn positive for $C$ albicans within 30 days in $20 \%$ to $25 \%$ of patients. Small numbers of the microorganisms persist, however, within the vaginal lumen, generally in numbers too small to be detected by conventional vaginal smear or cultures. Relapse due to non eradication is supported by the fact that short time recurrences are usually of the same biotype. ${ }^{2}$ In our patient group therapeutic regimens of previous symptomatic infections were not standardised (table 2). However, it was interesting to note that 15 out of 38 symptomatic episodes $(39 \%)$ could not be cured by short term treatment with second and third generation azole derivatives. In these patients symptomatic, culture proven infection persisted although male partners had been treated concomitantly, and strain specific resistance had been excluded by sensitivity tests. Drug interactions with antacids and $\mathrm{H} 2$ blocking agents could be excluded.

It has been demonstrated that zinc considerably participates in the growth and morphogenesis of $C$. albicans. Cultures of $C$. albicans enter a stationary phase owing to the depletion of zinc as well as in zinc excess conditions. ${ }^{14}$ Evidence has been presented that cells do not stop multiplying because of the depletion of nutrients from the supporting medium, but owing to the depletion of zinc..$^{15}$ Whereas first generation imidazoles showed fungicidal effects even on stationary-phase yeasts, second and third generation azoles, 
Table 2 Clinical data of 21 patients of symptomatic group

\begin{tabular}{|c|c|c|c|c|c|c|c|}
\hline $\begin{array}{l}\text { Patient } \\
\text { No. }\end{array}$ & $\begin{array}{l}\text { Age } \\
\text { (year) }\end{array}$ & $\begin{array}{l}\text { Duration of } \\
\text { Symptoms (year) }\end{array}$ & $\begin{array}{l}\text { No. of symptomatic } \\
\text { Infections per year }\end{array}$ & $\begin{array}{l}\text { Previous } \\
\text { treatments }\end{array}$ & $\begin{array}{l}\text { No of symptomatic } \\
\text { Episodes }\end{array}$ & $\begin{array}{l}\text { Treatment in our } \\
\text { department }\end{array}$ & $\begin{array}{l}\text { Treatment } \\
\text { results }\end{array}$ \\
\hline 1 & 38 & 15 & $5-6$ & local AA & $\begin{array}{l}1 \\
2 \\
3\end{array}$ & $\begin{array}{l}\text { fluconazole } 150 \mathrm{mg} \text { s.d. } \\
\text { itraconazole } 200 \mathrm{mg} \text { b.i.d. } / 1 \mathrm{~d} \\
\text { itraconazole } 100 \mathrm{mg} \text { b.i.d. } / 7 \mathrm{~d}\end{array}$ & $\begin{array}{l}\text { persistent infection } \\
\text { persistent infection } \\
\text { persistent infection }\end{array}$ \\
\hline 2 & 26 & 11 & 5 & $\begin{array}{l}\text { local AA } \\
\text { fluconazole }\end{array}$ & 4 & $\begin{array}{l}\text { ketoconazole } 400 \mathrm{mg} \text { o.d. } / 5 \mathrm{~d} / \\
\text { monthly } / 3 \text { months }\end{array}$ & cured $^{\star}$ \\
\hline 3 & 30 & 3 & 6 & $\begin{array}{l}\text { local AA } \\
\text { fluconazole }\end{array}$ & $\begin{array}{l}5 \\
6\end{array}$ & $\begin{array}{l}\text { fluconazole } 150 \mathrm{mg} \text { s.d. } \\
\text { itraconazole } 200 \mathrm{mg} \text { b.i.d./ } \\
\text { monthly } / 3 \text { months }\end{array}$ & $\begin{array}{l}\text { cured }^{\star} \\
\text { cured }^{\star}\end{array}$ \\
\hline 4 & 38 & 7 & 4 & $\begin{array}{l}\text { local AA } \\
\text { fluconazole }\end{array}$ & $\begin{array}{l}7 \\
8\end{array}$ & $\begin{array}{l}\text { fluconazole } 150 \mathrm{mg} \text { s.d. } \\
\text { fluconazole } 150 \mathrm{mg} / \\
\text { monthly } / 3 \text { months }\end{array}$ & $\begin{array}{l}\text { cured }^{\star} \\
\text { cured }^{\star}\end{array}$ \\
\hline 5 & 24 & 2 & 3 & local AA & 9 & fluconazole $150 \mathrm{mg}$ s.d. & cured $^{\star}$ \\
\hline 6 & 47 & 3 & 6 & local AA & 10 & fluconazole $150 \mathrm{mg}$ s.d. & cured $^{\star}$ \\
\hline 7 & 49 & 2 & 6 & local AA & $\begin{array}{l}11 \\
12\end{array}$ & $\begin{array}{l}\text { itraconazole } 200 \mathrm{mg} \text { b.i.d. } / 1 \mathrm{~d} \\
\text { itraconazole } 100 \mathrm{mg} \text { b.i.d. } / 7 \mathrm{~d}\end{array}$ & $\begin{array}{l}\text { persistent infection } \\
\text { persistent infection }\end{array}$ \\
\hline $\begin{array}{l}8 \\
9\end{array}$ & $\begin{array}{l}23 \\
38\end{array}$ & $\begin{array}{l}2 \\
2\end{array}$ & $3^{4-5}$ & $\begin{array}{l}\text { local AA } \\
\text { local AA }\end{array}$ & $\begin{array}{l}13 \\
14 \\
15\end{array}$ & $\begin{array}{l}\text { fluconazole } 150 \mathrm{mg} \text { s.d. } \\
\text { fluconazole } 150 \mathrm{mg} \text { s.d. } \\
\text { fluconazole } 150 \mathrm{mg} \text { s.d. }\end{array}$ & $\begin{array}{l}\text { persistent infection } \\
\text { cured } \\
\text { cured }^{\star}\end{array}$ \\
\hline 10 & 28 & 2 & 4 & local AA & $\begin{array}{l}16 \\
17\end{array}$ & $\begin{array}{l}\text { itraconazole } 200 \mathrm{mg} \text { b.i.d. } / 1 \mathrm{~d} \\
\text { fluconazole } 150 \mathrm{mg} \text { s.d. }\end{array}$ & $\begin{array}{l}\text { cured } \\
\text { cured }\end{array}$ \\
\hline 11 & 34 & 4 & 4 & local AA & 18 & $\begin{array}{l}\text { ketoconazole } 400 \mathrm{mg} \text { o.d./ } \\
\text { monthly } 3 \text { months }\end{array}$ & cured ${ }^{\star}$ \\
\hline 12 & 47 & 3 & 4 & local AA & $\begin{array}{l}19 \\
20\end{array}$ & $\begin{array}{l}\text { ketoconazole } 400 \mathrm{mg} \text { o.d. } / 5 \mathrm{~d} \\
\text { fluconazole } 150 \mathrm{mg} \text { s.d. }\end{array}$ & $\begin{array}{l}\text { persistent infection } \\
\text { cured }^{\star}\end{array}$ \\
\hline 13 & 23 & 9 & 5 & $\begin{array}{l}\text { local AA } \\
\text { fluconazole }\end{array}$ & $\begin{array}{l}21 \\
22\end{array}$ & $\begin{array}{l}\text { ketoconazole } 400 \mathrm{mg} / 5 \mathrm{~d} \\
\text { itraconazole } 200 \mathrm{mg} \text { b.i.d./1d }\end{array}$ & $\begin{array}{l}\text { cured } \\
\text { cured }^{\star}\end{array}$ \\
\hline $\begin{array}{l}14 \\
15\end{array}$ & $\begin{array}{l}28 \\
25\end{array}$ & $\begin{array}{l}2 \\
3\end{array}$ & $\begin{array}{l}3 \\
6\end{array}$ & $\begin{array}{l}\text { local AA } \\
\text { local AA } \\
\text { fluconazole }\end{array}$ & $\begin{array}{l}23 \\
24 \\
25\end{array}$ & $\begin{array}{l}\text { fluconazole } 150 \mathrm{mg} \text { s.d. } \\
\text { itraconazole } 200 \text { b.i.d. } / 1 \mathrm{~d} \\
\text { itraconazole } 100 \text { b.i.d. } / 7 \mathrm{~d}\end{array}$ & $\begin{array}{l}\text { cured }^{\star} \\
\text { persistent infection } \\
\text { persistent infection }\end{array}$ \\
\hline 16 & 25 & 8 & 4 & local AA & $\begin{array}{l}26 \\
27\end{array}$ & $\begin{array}{l}\text { fluconazole } 150 \mathrm{mg} \text { s.d. } \\
\text { fluconazole } 150 \mathrm{mg} \text { s.d. }\end{array}$ & $\begin{array}{l}\text { cured }^{\star} \\
\text { cured }^{\star}\end{array}$ \\
\hline 17 & 45 & 12 & $5-6$ & local AA & $\begin{array}{l}28 \\
29 \\
30\end{array}$ & $\begin{array}{l}\text { fluconazole } 150 \mathrm{mg} \text { s.d. } \\
\text { itraconazole } 200 \mathrm{mg} \text { b.i.d. } / 1 \mathrm{~d} \\
\text { itraconazole } 100 \mathrm{mg} \text { b.i.d. } / 7 \mathrm{~d}\end{array}$ & $\begin{array}{l}\text { persistent infection } \\
\text { persistent infection } \\
\text { persistent infection }\end{array}$ \\
\hline 18 & 31 & 2 & $4-5$ & local AA & $\begin{array}{l}31 \\
32 \\
33\end{array}$ & $\begin{array}{l}\text { fluconazole } 150 \mathrm{mg} \text { s.d. } \\
\text { itraconazole } 200 \mathrm{mg} \text { b.i.d. } / 1 \mathrm{~d} \\
\text { itraconazole } 100 \mathrm{mg} \text { b.i.d. } / 7 \mathrm{~d}\end{array}$ & $\begin{array}{l}\text { persistent infection } \\
\text { persistent infection } \\
\text { persistent infection }\end{array}$ \\
\hline $\begin{array}{l}19 \\
20\end{array}$ & $\begin{array}{l}21 \\
41\end{array}$ & $\begin{array}{l}4 \\
2\end{array}$ & $\begin{array}{l}4-5 \\
3-4\end{array}$ & $\begin{array}{l}\text { local AA } \\
\text { local AA }\end{array}$ & $\begin{array}{l}34 \\
35 \\
36\end{array}$ & $\begin{array}{l}\text { itraconazole } 200 \mathrm{mg} \text { b.i.d. } / 1 \mathrm{~d} \\
\text { itraconazole } 200 \mathrm{mg} \text { b.i.d. } / 1 \mathrm{~d} \\
\text { itraconazole } 200 \mathrm{mg} \text { b.i.d. } / 1 \mathrm{dd}\end{array}$ & $\begin{array}{l}\text { cured }{ }^{\star} \\
\text { cured } \\
\text { cured }^{\star}\end{array}$ \\
\hline 21 & 40 & 3 & 4 & local AA & $\begin{array}{l}37 \\
38\end{array}$ & $\begin{array}{l}\text { fluconazole } 150 \mathrm{mg} \text { s.d. } \\
\text { itraconazole } 200 \mathrm{mg} \text { b.i.d. } / 1 \mathrm{~d}\end{array}$ & $\begin{array}{l}\text { cured }^{\star} \\
\text { cured }\end{array}$ \\
\hline
\end{tabular}

AA: Azole Antifungals, s.d.: single dose, ${ }^{\star}$ follow up for cured patients ranged between 5 and 8 months

such as ketoconazole and the triazoles are never more than fungistatic. ${ }^{16}$ The primary target is the cellular membrane, owing to the inhibition of ergosterol biosynthesis by blocking a cytochrome P-450 dependent 14-alphademethylase. Prerequisite for successful antifungal treatment in case of fungistasis is the growing, multiplying, protein-synthesising cell. Therapeutic failure of second and third generation azoles could be due to local cervicovaginal zinc conditions favouring a surplus of stationary phase yeasts. However, these hypotheses are unproven and require additional studies to clarify the zinc status of cervicovaginal secretion during symptomatic infection. Furthermore zinc levels in symptomatic patients must be correlated with treatment results. Finally controlled studies should help to clarify whether zinc supplementation effects clinical cure rate of VVC.

In conclusion our study could not confirm the hypothesis that zinc deficiency is a risk factor in recurrent VVC. From the available data of this pilot study the zinc levels of cervicovaginal secretions might influence antifungal activity of third generation azole antimycotics.

1 Sobel JD. Pathophysiology of Vulvovaginal Candidiasis. $\mathcal{f}$ Reprod Med 1989;34, Suppl:572-80.

2 Odds FC. Candidosis of the genitalia. In Odds FC, ed,
Candida and Candidosis 2nd ed. London, Bailliere, Tindall, 1988;124-35.

3 Witkin SS, Yu RI, Ledger WJ. Inhibition of Candida albicans induced lymphocyte proliferation by lymphocytes and sera from women with recurrent vaginitis. $A m \mathcal{F}$ Obstet Gynecol 1983;147:809-12.

4 Witkin SS, Hirsch J, Ledger WJ. A macrophage defect in women with recurrent Candida vaginitis and its reversal in vitro by prostaglandin inhibitors. Am f Obstet Gynecol 1986;155:790-95.

5 Chipperfield EJ, Evans BA. The influence of local infection on immunoglobulin formation in the human endocervix. Clin Exp Immunol 1972;11:219-23.

6 Cunningham-Rundles S, Cunningham-Rundles WF. Zinc modulation of immune response. In Chandra RK ed. Contemporary Issues in Clinical Nutrition 11, Nutrition and Immunology New York Alan R Liss, 1988;197-210.

7 Edman J, Sobel JD, Taylor ML. Zinc status in women with recurrent vulvovaginal candidiasis. Am $f$ Obstet Gynecol 1986;155:1082-5.

8 Anderson J, Soll DR. Effects of zinc on stationary-phase phenotype and macromolecular synthesis accompanying outgrowth of Candida albicans. Infect. Immun. 1984;46: 13-21.

9 Raulin J. Etudes chimiques sur la vegetation. Ann Sci Natl Botan Biol Vegetale 1869;11:93-8.

10 Prasad AS, Miale A, Farid Z, et al. Zinc metabolism in normals and patients with the syndrome of iron deficiency anemia, hypogonadism and dwarfism. f Lab Clin Med 1963;61:537-9.

11 Moynahan EJ, Barnes PM. Zinc deficiency and a synthetic diet for lactose intolerance. Lancet 1973;i:676-80.

12 Beisel WR. Single nutrients and Immunity. Am $\mathcal{F}$ Clin Nutr 1982;35:417-68.

13 White DJ, Emens M, Shahmanesh M. Recurrent vulvovaginal candidosis. Int $\mathcal{F}$ STD AIDS 1991;2:235-9.

14 Bedell GW, Soll DR. Effects of low concentrations of zin on the growth and dimorphism of Candida albicans. evidence for zinc-resistant and -sensitive pathways: for mycelium formation. Infect Immun 1979;26: 348-54.

15 Soll DR, Bedell GW, Brummel M. Zinc and the regulation of growth and phenotype in the infectious yeast Candida albicans. Infect Immun 1981;32:1139-47.

16 Odds FC. Antifungal agents and their use in candida infection. In: Odds FC ed. Candida and Candidosis 2 nd ed. London, Bailliere, Tindall. 1988;279-313. 